\title{
Smoking has physical and psychoactive effects, and heavy smoking is associated with depression
}

\author{
Netti HERAWATI ${ }^{1}$, Shosuke SUZUKI ${ }^{2}$, Hiroshi KOYAMA ${ }^{3}$ \\ and Kunihiko HAYASHI ${ }^{4}$
}

The effects of smoking on physical and mental health were assessed in a cohort of 3,376 middle-aged men by a health questionnaire, the Total Health Index, and by mortality risk ratio. Participants were grouped into the four following smoking classes: never smoked, smoke 1-19, 20-29, and $\geq 30$ cigarettes a day. The Index has 15 physical and mental symptom scales that assess his perceived health of respiratory organs, digestive organs, short temper, depression, aggressiveness, et al. Each scale score was calculated as the sum of the positive number of symptoms, and a higher score indicates more symptoms. Starting from never smoked class, mean respiratory organ scale score increase linearly depending on the heavier smoking classes. Mean digestive organ scale score and the other three scale scores also showed linear dose-response relationship with the three classes of increasing number of cigarettes smoked a day.

The other seven scale scores showed not a linear but J-shaped dose-response relationship. The never-smoked, smoke 1-19, and 20-29 cigarettes per day classes showed no increased response; only the heaviest class, smoke $\geq 30$ cigs or more a day, had significantly higher mean scores for vague complaints, short temper, anxiety, depression, mouth, eye, and neurotics. Mortality risk of lung cancer was also high in heavy smokers $(\mathrm{RR}=3.71)$. Men of depression included more heavy smokers than the other non-depression men $(\mathrm{P}=0.0014)$.

Key words : heavy smoking; physical health; mental effect; mortality risk; depression

\section{Introduction}

Smoking, a leading cause of lung cancer globally, has psychotropic effects, as well as a detrimental effect on physical health. Over the past 25 years, researchers have uncovered strong evidence for a relationship between smoking and health in many countries, including Japan, the US, Australia, the UK, France, Brazil, and Korea. ${ }^{1-9)}$
Associations between smoking and physical and mental health have been thoroughly examined in adolescents and people with psychiatric disorders. ${ }^{10-15)}$ In the present study, a questionnaire, the Total Health Index (THI) was used to assess the relationship of smoking classes and perceived physical and mental health ${ }^{16,17)}$ in a cohort of middle-aged men. We report smoking-related risks of depression and mortality of all causes of death and

\footnotetext{
${ }^{1}$ Department of Mathematics, Faculty of Sciences, University of Lampung, Indonesia

${ }^{2}$ Non-Profit Organization of International Eco-Health Research Group, Japan

${ }^{3}$ Department of Public Health, Gunma University Graduate School of Medicine, Japan

${ }^{4}$ Department of Basic Medical Sciences, School of Health Sciences, Gunma University Graduate School of Medicine, Japan
} 
of lung cancer (C34: symbol of International Classification of Disease, 10th Edition, or ICD-10).

Several studies have demonstrated that depression is related to smoking, but only a few studies have shown this in Japan ${ }^{13)}$. Thus, in the present study, we assessed the effects of smoking on physical and mental health, with a special emphasis on the association between heavy smoking and depression in middle-aged men in Japan.

\section{Methods}

Residents of 5,632 men aged 40-69 years living in Komochi Village and Isesaki City in Gunma Prefecture, Japan, were first surveyed in 1993 in a cohort named the Komo-Ise Study ${ }^{1-3)}$. The second survey was performed in 2000. Cases of deaths and migrations were collected from the municipal Basic Resident Registers of the local government having got permissions of the Ministry of Health and Welfare, Government of Japan, from 1993 to 2011 for 18 years. All men completed a written health questionnaire that included a symptom assessment scale, the THI, to assess perceived health ${ }^{1-3,16,17)}$. The following cases were excluded from the present survey leaving a final total of 4,116 men: 184 censored cases; 503 men who did not participate in the second survey; and 829 men who had many missing or error answers in the questionnaire. More than 20 academic reports have been published from the cohort data base of the Komo-Ise survey including the THI findings and the mortality risks. ${ }^{1-3,18-23)}$

\section{Study Variables}

The 4,116 men were classified into the following classes according to cigarettes consumption: had never smoked ( $\mathrm{n}=1,119)$; quitted smoking $(\mathrm{n}=740)$; and were current smokers $(\mathrm{n}=2,257)$. The cohort of 3,376 men (all participants except 740 men who had quit smoking) were classified into the following four classes: never smoked $(n=1,119)$; smoke
1-19 cigarettes/day $(\mathrm{n}=635)$; smoke $20^{-}-29$ cigarettes/day $(\mathrm{n}=1,024)$; and smoke $\geq 30$ cigs/day $(\mathrm{n}=598)$. Physical and psychotropic symptoms were assessed using average THI scale scores, which were calculated separately for the four smoking classes (Table 1). The unit of scale score of Table 1 is cumulative \%tile or ranking of his positive number of respiratory organ symptoms. The least symptom of respiratory organ as $1 \%$ tile to the maximum number of symptoms as $100 \%$ tile in a representative men population. Furthermore, the proportion (\%) of heavy smokers were calculated in the seven classes of depression men by the THI.

\section{Statistical Analysis}

A multivariate analysis of variance (MANOVA) was used to evaluate the associations between smoking level and THI scale scores. The associations ware tested between the four smoking classes for the average scale score of the THI by Bonferroni tests. Mortality risks and relative risks were estimated with $95 \%$ confidence intervals (CIs) based on cumulative mortality during the fixed study period. The association between depression scale scores classes and heavy smokers \% was tested by the chi-squared $(\chi 2)$ test. Data were analyzed using SPSS/PC ver. 19 statistical package (SPSS, Chicago, IL, USA) and SAS ver. 9.4 (SAS Institute Inc., NC, USA). All reported $\mathrm{p}^{-}$-values are two tailed and those less than 0.05 were considered as statistically significant.

Ethical approval for this study was granted by the Gunma University Epidemiological Research Ethics Committee (No. 16-5, 2004) and by the Research Ethics Committee of NOP of International Eco-Health Research Group (No. 1, 2012).

\section{Results}

Table 1 shows the average scores of the $15 \mathrm{THI}$ scales for the four smoking classes, as well as the results of the MANOVA and Bonferroni test. The 
Table 1 Average scale scores in cummulated \%tile of THI, the Total Health Index, of the four classes of men by smoking level from the Komo-lse cohort men, tested by Bonferroni Statistics, which identified the three types of dose-response relationship, a-b-c, a-a-b, and a-a-a.

\begin{tabular}{|c|c|c|c|c|c|c|c|}
\hline \multicolumn{2}{|l|}{ THI Scales } & $\begin{array}{l}\text { Never Smoked } \\
\qquad \mathrm{N}=712\end{array}$ & $\begin{array}{c}1-19 \text { cigs/day } \\
\mathrm{N}=535\end{array}$ & $\begin{array}{c}20-29 \text { cigs/day } \\
\qquad N=880\end{array}$ & $\begin{array}{c}\geq 30 \text { Cigs/day } \\
N=522\end{array}$ & $\mathrm{~F}$ & $\mathrm{P}-$ Value $\dagger$ \\
\hline \multicolumn{8}{|l|}{ Type $a^{-} b^{-} c^{*}$} \\
\hline \multirow[t]{2}{*}{ Respiratory Organs } & mean $\pm \mathrm{SD}$ & $49.4 \pm 27.0 \mathrm{a}$ & $53.5 \pm 26.7 \mathrm{~b}$ & $56.0 \pm 26.9 \mathrm{~b}$ & $60.6 \pm 25.4 \mathrm{c}$ & 3115.9 & 0.000 \\
\hline & $95 \% \mathrm{CI}$ & $47.9-51.0$ & $51.2-55.8$ & $54.2-57.8$ & $58.3-62.9$ & & \\
\hline \multirow[t]{2}{*}{ Digestive Organs } & mean $\pm \mathrm{SD}$ & $52.6 \pm 24.9 \mathrm{a}$ & $53.3 \pm 25.5 a$ & $57.6 \pm 25.3 b$ & $64.7 \pm 24.6 \mathrm{c}$ & 3821.6 & 0.000 \\
\hline & $95 \% \mathrm{CI}$ & $51.1-54.1$ & $51.2-55.5$ & $55.9-59.2$ & $62.5-66.8$ & & \\
\hline \multirow[t]{2}{*}{ Morning-Eveningness } & mean $\pm \mathrm{SD}$ & $49.6 \pm 27.8 \mathrm{a}$ & $51.2 \pm 27.2 \mathrm{a}$ & $56.2 \pm 26.9 \mathrm{~b}$ & $64.2 \pm 27.1 \mathrm{c}$ & 3024.8 & 0.000 \\
\hline & $95 \% \mathrm{CI}$ & $48.0-51.3$ & $48.9-53.5$ & $54.4-56.0$ & $61.8-66.5$ & & \\
\hline \multirow[t]{2}{*}{ Total Scale of Body \& Mind } & mean $\pm \mathrm{SD}$ & $45.8 \pm 29.1 \mathrm{a}$ & $47.9 \pm 28.4 \mathrm{a}$ & $52.8 \pm 27.7 \mathrm{~b}$ & $54.3 \pm 28.2 \mathrm{c}$ & 2394.9 & 0.000 \\
\hline & $95 \% \mathrm{CI}$ & $46.5-49.9$ & $45.4-50.3$ & $50.9-54.7$ & $51.8-56.7$ & & \\
\hline \multirow[t]{2}{*}{ Schizophrenia } & mean $\pm \mathrm{SD}$ & $53.5 \pm 28.2 \mathrm{a}$ & $50.0 \pm 28.7 \mathrm{a}$ & $47.5 \pm 29.3 \mathrm{~b}$ & $43.7 \pm 28.4 \mathrm{c}$ & 2262.7 & 0.000 \\
\hline & $95 \% \mathrm{CI}$ & $51.8-55.2$ & $47.6-52.5$ & $45.6-49.4$ & $41.3-46.2$ & & \\
\hline \multicolumn{8}{|l|}{ Type $a^{-} a^{-} b^{*}$} \\
\hline \multirow[t]{2}{*}{ Mouth and Anus } & mean $\pm \mathrm{SD}$ & $55.6 \pm 25.9 \mathrm{a}$ & $53.2 \pm 25.9 \mathrm{a}$ & $56.0 \pm 25.3 \mathrm{a}$ & $61.5 \pm 25.0 \mathrm{~b}$ & 3681.1 & 0.000 \\
\hline & $95 \% \mathrm{CI}$ & $54.0-57.1$ & $51.0-55.3$ & $54.3-57.7$ & $59.3-63.7$ & & \\
\hline \multirow[t]{2}{*}{ Eye and Skin } & mean $\pm \mathrm{SD}$ & $54.1 \pm 27.2 \mathrm{a}$ & $53.7 \pm 27.0 \mathrm{a}$ & $54.5 \pm 25.8 \mathrm{a}$ & $60.4 \pm 27.0 \mathrm{~b}$ & 3266.8 & 0.000 \\
\hline & $95 \% \mathrm{CI}$ & $53.2-56.4$ & $51.4-56.0$ & $52.7-56.2$ & $58.1-62.7$ & & \\
\hline \multirow[t]{2}{*}{ Vague Complaints } & mean $\pm \mathrm{SD}$ & $49.5 \pm 28.3 \mathrm{a}$ & $49.5 \pm 27.8 \mathrm{a}$ & $52.4 \pm 27.6 \mathrm{a}$ & $59.1 \pm 26.1 b$ & 2690.5 & 0.000 \\
\hline & $95 \% \mathrm{CI}$ & $47.7-51.1$ & $47.1-51.8$ & $50.6-54.2$ & $56.8^{-} 61.5$ & & \\
\hline \multirow[t]{2}{*}{ Short Temper } & mean $\pm \mathrm{SD}$ & $50.8 \pm 28.7 \mathrm{a}$ & $52.3 \pm 28.7 \mathrm{a}$ & $52.2 \pm 28.7 \mathrm{a}$ & $60.8 \pm 28.4 b$ & 2627.4 & 0.000 \\
\hline & $95 \% \mathrm{CI}$ & $49.1-52.5$ & $49.9-54.7$ & $50.3-54.1$ & $58.4-63.3$ & & \\
\hline \multirow[t]{2}{*}{ Anxiety } & mean $\pm \mathrm{SD}$ & $52.6 \pm 28.5 a$ & $52.4 \pm 27.7 \mathrm{a}$ & $51.8 \pm 27.6 \mathrm{a}$ & $57.5 \pm 27.2 \mathrm{~b}$ & 2757.2 & 0.000 \\
\hline & $95 \% \mathrm{CI}$ & $50.9-54.3$ & $50.0-54.7$ & $49.9-53.6$ & $55.1-59.9$ & & \\
\hline \multirow[t]{2}{*}{ Neurotics } & mean $\pm \mathrm{SD}$ & $48.2 \pm 28.6 \mathrm{a}$ & $48.8 \pm 28.4 \mathrm{a}$ & $48.9 \pm 28.4 \mathrm{a}$ & $53.7 \pm 29.0 \mathrm{~b}$ & 2272.5 & 0.000 \\
\hline & $95 \% \mathrm{CI}$ & $46.5-49.9$ & $46.3-51.2$ & $47.0-50.8$ & $51.2-56.1$ & & \\
\hline \multirow[t]{2}{*}{ Depression } & mean $\pm \mathrm{SD}$ & $53.9 \pm 25.6 \mathrm{a}$ & $53.5 \pm 25.8 \mathrm{a}$ & $54.1 \pm 25.6 \mathrm{a}$ & $59.2 \pm 26.2 b$ & 3422.5 & 0.000 \\
\hline & $95 \% \mathrm{CI}$ & $52.3-55.4$ & $51.3-55.7$ & $52.3-55.7$ & $57.1-61.5$ & & \\
\hline \multicolumn{8}{|l|}{ Type $a^{-} a^{-} a^{*}$} \\
\hline \multirow[t]{2}{*}{ Aggressiveness } & mean $\pm \mathrm{SD}$ & $55.2 \pm 28.7 \mathrm{a}$ & $57.3 \pm 29.0 \mathrm{a}$ & $58.6 \pm 28.1 \mathrm{a}$ & $58.3 \pm 29.1 \mathrm{a}$ & & \\
\hline & $95 \% \mathrm{CI}$ & $53.5-56.9$ & $54.9-59.7$ & $56.7-60.5$ & $55.9-60.8$ & 3007.9 & 0.048 \\
\hline \multirow[t]{2}{*}{ Nervousness } & mean $\pm \mathrm{SD}$ & $53.5 \pm 28.9 \mathrm{a}$ & $54.4 \pm 28.9 \mathrm{a}$ & $51.3 \pm 28.3 \mathrm{a}$ & $54.9 \pm 29.4 \mathrm{a}$ & & \\
\hline & $95 \% \mathrm{CI}$ & $51.8-55.2$ & $52.0-56.9$ & $49.4-53.2$ & $52.0-57.4$ & 2590.4 & 0.086 \\
\hline \multirow[t]{2}{*}{ Psychosomatics } & mean $\pm \mathrm{SD}$ & $49.9 \pm 28.4 \mathrm{a}$ & $48.6 \pm 29.0 \mathrm{a}$ & $48.0 \pm 28.2 \mathrm{a}$ & $50.6 \pm 29.3 \mathrm{a}$ & & \\
\hline & $95 \% \mathrm{CI}$ & $48.2-51.6$ & $46.2-51.1$ & $46.1-49.9$ & $48.1-53.0$ & 2243.9 & 0.293 \\
\hline
\end{tabular}

*: Bonferroni test, no significant difference if mean followed by the same letters, significant difference otherwise.

$\dagger: \mathrm{P}-$ value $<0.05$, significant difference among the four means of scale score of smoking classes, based on MANOVA. 
Bonferroni test revealed three effect types for the average THI scale scores between the four smoking classes. The three effect types were coded as $a^{-} b^{-}-a^{-} a^{-} b$, and $a^{-} a^{-} a$.

The $a^{-} b^{-} c$ effect type reflects a significant difference between a smoking class and the adjacent smoking class in all the four smoking classes. This means that the more the men smoked, the more symptoms they reported. This pattern was found in the comparisons between the classes of never smoked, smoke $1-19,20^{-} 29$, and $>30$ cigs/day. This linear dose-response pattern was observed in the following five THI symptom scales: Respiratory (frequent coughing, phlegm, or sneezing, and throat irritation or pain); Digestive (stomachache or discomfort, indigestion, and diarrhea); Eveningness lifestyle or chronotype (stays up late, gets up late, often skips breakfast, irregular meals, poor appetite, and low energy); Total body and mind symptoms and complaints; and Low-to-high schizophrenia tendency (Table 1).

The respiratory organ THI scale was most sensitive to smoking stress; there was a significant difference between the average scores of the never-smoking and smoke 1-19 cigs/day groups ( $p=0.001$; Bonferroni test), and no other between-group differences in the other four scale scores. A linear ascent dose-response relationship was seen in four of the THI scales, and this relationship was descent only in the schizophrenia scale.

The $a^{-}-a^{-} b$ effect type indicated that no significant differences were found between the first three smoking classes (never smoking, smoke 1-19, and 20-29 cigs/day) in the average scores of the seven following THI scales: Mouth and anus (rough tongue, swollen or bleeding gums, bad breath, constipation, piles, and bleeding hemorrhoids); Eyes and skin (itchy, hot or red eyes, rough, itchy or sensitive skin, and a rash); Vague complaints (feel- ing tired, sluggish, heavy, or languid, headaches or dull aches, a desire to lie down, and general malaise); Short temper (easily irritated, loss of temper, acting without considering the consequences, and getting upset); Anxiety (worrying about small things, feeling uneasy when one's work is observed by others, nervous or shaky, feeling weak, worrying about the past, frequent cold sweats, and feeling mentally tired or depressed); Neurotics (could be diagnosed as it by THI); and Depression (could be diagnosed as it when the score was 22 points or more). However, there were significant differences in the average scores of these seven scales between the never smoking to smoke 1-19, and 20-29 and 30 cigs/day or more classes as shown in Table 1. The $\mathrm{a}^{-} \mathrm{a}^{-} \mathrm{b}$ effect type showed $\mathrm{a}$ $\mathrm{J}$-shaped dose-response relationship.

The $\mathrm{a}^{-} \mathrm{a}^{-} \mathrm{a}$ effect type indicated there were no significant differences $(P \geq 0.05)$ in the average scale scores between the four smoking classes in the three following THI scales: Aggressiveness (positive and active, not timid, never dizzy, often drinks a lot, and is overweight); Nervousness (nervous, sensitive, worries about cleanliness); and Psychosomatics (could be diagnosed as it by THI) (Table 1).

Table 2 shows the prevalence (\%) of depression diagnosed by the THI, and cumulative mortality rates by all causes and by lung cancer (C34 in the ICD-10) for the four smoking classes of the Komo-Ise cohort of 3,376 or 4,116 men. The risk ratio of depression was highest in the heaviest smoker class ( $R R=1.423)$ among all the four classes.

Men who smoke 30 cigs/day or more had the highest mortality risk ratio of lung cancer (C34), $\mathrm{RR}=3.71$, compared with the other smoking groups (20-29 cigs/day: $\mathrm{RR}=1.42 ; 1-19$ cigarettes/day: $\mathrm{RR}=0.94$; had never smoked: $\mathrm{RR}=1.00$ ). Mortality risk ratios of all causes of death were 1.81, 1.88, 1.59 , and 1.00, respectively (Table 2). Fig. 1 shows 
Table 2 Rates of depression, mortality risk by all causes, and mortality risk by lung cancer (C34) in men of Komo-Ise cohort from 1993 to 2011, classified into four classes according to smoking levels

\begin{tabular}{|c|c|c|c|c|c|c|c|c|c|c|c|c|c|c|c|c|}
\hline \multirow[b]{2}{*}{$\begin{array}{c}\text { Four Smoking } \\
\text { Groups }\end{array}$} & \multicolumn{3}{|c|}{ Depression } & \multicolumn{7}{|c|}{ Cumulative Mortality Rate and Risk by All Causes } & \multicolumn{6}{|c|}{ Cumulative Mortality Rate and Risk by Lung Cancer (C34) } \\
\hline & 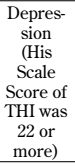 & $\begin{array}{c}\text { Depres- } \\
\text { sion } \\
\text { Preva- } \\
\text { lence, } \%\end{array}$ & $\begin{array}{c}\text { Depres- } \\
\text { sion Risk } \\
\text { Ratio }\end{array}$ & $\mathrm{N}$ & $\begin{array}{c}\text { Number } \\
\text { of } \\
\text { Deaths } \\
\text { by All } \\
\text { Causes }\end{array}$ & \begin{tabular}{|c|} 
Cumula- \\
tive \\
Mortality \\
Rate by \\
All \\
Causes, \\
$\%$
\end{tabular} & $\begin{array}{c}95 \% \text { CI of } \\
\text { Cumula- } \\
\text { tive } \\
\text { Mortality } \\
\text { Rate by } \\
\text { All } \\
\text { Causes }\end{array}$ & $\begin{array}{c}\text { Mortality } \\
\text { Risk } \\
\text { Ratio by } \\
\text { All } \\
\text { Causes }\end{array}$ & $\begin{array}{c}95 \% \text { CI of } \\
\text { Mortality } \\
\text { Risk } \\
\text { Ratio by } \\
\text { All } \\
\text { Causes }\end{array}$ & P-Value & $\begin{array}{c}\text { Deaths } \\
\text { by Lung } \\
\text { Cancer } \\
(\mathrm{C} 34 / \mathrm{N})\end{array}$ & \begin{tabular}{|c|} 
Cumula- \\
tive \\
Mortality \\
Rate by \\
Lung \\
Cancer, \% \\
(C34) \\
\end{tabular} & \begin{tabular}{|c|}
$95 \%$ CI of \\
Cumula- \\
tive \\
Mortality \\
Rate by \\
Lung \\
Cancer \\
(C34) \\
\end{tabular} & \begin{tabular}{|c|} 
Cumula- \\
tive \\
Mortality \\
Risk \\
Ratio by \\
Lung \\
Cancer \\
(C34) \\
\end{tabular} & \begin{tabular}{|c|} 
\\
$95 \%$ CI of \\
Mortality \\
Risk by \\
Lung \\
Cancer \\
\end{tabular} & P-Value \\
\hline $\begin{array}{l}\text { Never smoked } \\
\& \text { q u it t e d, } \\
1,859 \text { men }^{*}\end{array}$ & 67 & 3.60 & 1.00 & $1,859^{*}$ & 179 & 9.63 & $\begin{array}{l}8.08- \\
11.85\end{array}$ & 1.00 & $0.82-1.22$ & 1.000 & $5 / 1,119$ & 0.45 & $0.06-0.84$ & 1.00 & $0.29-3.44$ & 1.00 \\
\hline $\begin{array}{l}1-19 \text { cigs } / \text { day } \\
635 \text { men }\end{array}$ & 25 & 3.93 & 0.956 & 635 & 97 & 15.28 & $\begin{array}{l}12.39- \\
18.63\end{array}$ & 1.59 & $1.26^{-}-1.99$ & $<0.0001$ & $6 / 635$ & 0.94 & $0.19-1.69$ & 2.09 & $0.65-6.90$ & 0.21 \\
\hline $\begin{array}{c}20-29 \text { cigs/day } \\
1,024 \text { men }\end{array}$ & 31 & 3.02 & 0.734 & 1024 & 185 & 18.07 & $\begin{array}{l}15.56- \\
20.87\end{array}$ & 1.88 & $1.55-2.27$ & $<0.0001$ & $7 / 1,024$ & 0.68 & $0.18^{-1.19}$ & 1.42 & $0.49-4.81$ & 0.45 \\
\hline $\begin{array}{c}>30 \mathrm{cigs} / \text { day } \\
598 \mathrm{men}\end{array}$ & 35 & 5.85 & 1.423 & 598 & 104 & 17.39 & $\begin{array}{r}14.21- \\
21.07 \\
\end{array}$ & 1.81 & $1.44-2.26$ & $<0.0001$ & $10 / 598$ & 1.67 & $0.64-2.70$ & 3.71 & $1.29-10.89$ & 0.02 \\
\hline
\end{tabular}

*: Sum of 1,119 men who never smoked and 740 men who had quitted smoking.

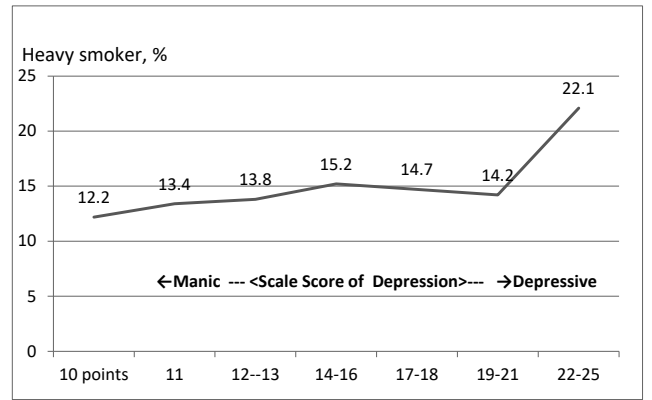

Fig. 1 Prevalence (\%) of heavy smokers ( $>30 \mathrm{Cig} /$ day) in seven classes of men on the manic-depression scale. This scale has 10 qestions or items and each item has three answers: \{yes, intermediate, no\} or 3, 2 and 1 points given, each. The sum of the points is his scale score point. Scale score of 22 points or more is the cut-off point of depression from the normals and manics. It is notable that the depression men has the highest prevalence (\%) of heavy smokers, with $p=0.0014$.

seven groups that were classified according to THI depression scale scores, ranging from manic (a score of 10) to depression (a score of 22 or more). The depression group had a significantly higher proportion (\%) of heavy smokers $\left(22.1 \% ; \chi^{2}=\right.$ $-3.586, \mathrm{P}=0.000335 ; \chi$-squared test), and the other six groups with lower depression scores had a lower proportion (\%) of heavy smokers, ranging from 12.2 to $15.2 \%$.

\section{DISCUSSION}

Our data indicate that smoking has a significant effect on physical health and a slight effect on psychotropic or mental health. The average THI scale scores revealed that smoking increased complaints and symptoms of the respiratory organs, digestive organs, mouth and anus, total scores of body and mind symptoms, vague complaints, morningness- ${ }^{-}$eveningness chronotype, eyes and skin, short temper, anxiety, neurotics, and depression. These findings support the theory that smoking affects physical health and that heavier smoking increases the risk of physical diseases.

Smoking produces tar particulates that stimulate the upper respiratory tracts and enter into deep terminal tissue of the lung. The tar also enters into the digestive organs, it can cause serious conditions. The digestive organs of the male smokers in this survey were found to be significantly affected, depending on smoking levels, such that men who smoke $\geq 30$ cigs/day had most of these adverse effects including stomachache, indigestion, and diarrhea ( $\mathrm{CI} 62.5-66.8 ; \mathrm{P}<0.0000)$. This is in line with our findings of a significant effect of smoking on the mouth and anus including rough tongue, swollen or bleeding gums, bad breath, constipation, piles, and bleeding hemorrhoids $(\mathrm{P}<0.0000)$. Similarly, smoking has been reported to have various effects on the digestive organs and to be a risk factor for gastrointestinal ulcers. ${ }^{22,23)}$

The heavy smokers in this study complained 
more of cough, phlegm, sneezing and indigestion, and were more likely to sit up late at night showing an eveningness chronotype $(\mathrm{P}<0.000)$. Smokers have been reported significantly more likely to suffer from insomnia and to complain daytime sleepiness than non- ${ }^{-}$smokers. ${ }^{24,25)}$

Smoking has adverse effects on physiological and emotional processes. Our results indicate that the average scale scores of body and mind total symptoms, vague complaints, and short temper, increased related to smoking levels $(\mathrm{P}<0.001)$. Those who smoke $\geq 30$ cigs/day had the highest average total scores for body and mind symptoms, vague complaints, and short temper, with $\mathrm{CI}$ values of 51.8-56.7, 56.8-61.5, and 58.4-63.3, respectively.

A reverse effect was found of smoking level and symptoms of schizophrenia. Men who smoke $\geq 30$ cigs/day had the lowest score in the schizophrenia scale $(43.7 \pm 28.4)$ than never-smokers $(53.5 \pm$ 28.2) and light or moderate smokers. This indicates that smoking does not lead to schizophrenia, which supports preceded findings. ${ }^{26)}$

In this study, we found that heavy smokers had a higher average anxiety level $(57.5 \pm 27.2)$ than the other smoking groups. This is consistent with the finding that smoking increases the risk of anxiety disorders during not middle age but during late adolescence. $^{27)}$

Concerning the association between smoking level and depression, we found that the proportion of heavy smokers in depressed men with THI scale score of 22 or more was higher than that of the other less depressed men. These results are consistent with preceded studies that have reported close associations between depression and a high proportion of heavy smoker in Western populations. ${ }^{12,28)}$ Similarly, a national survey of adults in USA, conducted from 2005 to 2008 , found a strong association between depression and smoking. ${ }^{29)}$

In our study, mortality rate by all causes of death was higher in smokers than in non-smokers. Similar results were obtained for the cumulative mortality rate and risk ratio of lung cancer. Men who smoke $\geq 30$ cigs/day had a mortality rate and mortality risk ratio of 1.67 and 3.71 (CI 1.29-10.89), respectively. Heavy smokers are more likely to develop lung cancer than those who smoke less. This finding is consistent with preceded research showing that lung cancer mortality increases to almost $40 \%$ at the highest smoking level $\left(>42\right.$ cigs/day) ${ }^{30)}$ and that current smokers are 25 times more likely to die from lung cancer than those who have never smoked. ${ }^{31)}$ Smoking habit was surveyed in more detailed in the second survey in 2000. Net years of smoking will be informed for every smoker. Smoking history of 740 quitted men will also be made clear of the years of smoking and number of cigarettes smoked a day. Present data on smoking could be improved to more detailed and finer one in future.

\section{CONCLUSION}

This study provides evidence that smoking has specific effects on perceived physical health, and also has some psychotropic effects. A close association between heavy smoking and depression was found in this Japanese cohort.

\section{Acknowledgements}

This study was financially supported by the NPO International Eco-Health Research Group in 2014. We would like to thank Dr. Hisaka Iijima of the NPO for her expert advice, and the mayors and staff of Komochi Village and Isesaki City. We also thank Nia Cason, PhD, from Edanz Group (https://en-author-services.edanzgroup.com/ac) for editing a draft of this manuscript. The authors declare that there are no conflicts of interest. 


\section{References}

1) Wang N, Iwasaki M, Otani T, et al. Perceived health as related to income, socio-economic, status, lifestyle, and social support factors in a middle-aged Japanese. J Epidemiol 2005; 15(5): 155-62.

2) Iwasaki M, Otani T, Ohta, A, et al. Rural-urban differences in socio-demographic, social network and lifestyle factors related to mortality of middle-aged Japanese men from the Komo-Ise cohort study. J Epidemiol 2002; 12(2): 93-104.

3) Asano H, Takeuchi K, Sasazawa Y, et al. Distribution of scale score of a health questionnaire, THI, based on a new standard population of Japanese men and women workers. Kosei no Shihyo 2005; 52(7): 1-7 (in Japanese).

4) Banks E, Joshy G, Weber MF, et al. Tobacco smoking and all-cause mortality in a large Australian cohort study: findings from a mature epidemic with current low smoking prevalence. BMC Med 2015; 13: 38 .

5) Richardson S, McNeill A, Brose LS. Smoking and quitting behaviors by mental health conditions in Great Britain (1993-2014). Addict Behav 2019; 90: 14-19.

6) Tanaka H, Sasazawa Y, et al. Health status and lifestyle factors as predictors of depression in middle-aged and elderly Japanese adults: a seven-year follow ${ }^{-}$up of the Komo-Ise cohort study. BMC Psychiatry 2011; 11:20, 1-10.

7) Lee J, Kim TH, et al. Depressive symptoms and suicidal behaviors in adolescent non-daily smokers compared to daily smokers and never smokers in Korea: National cross-sectional study. PloS ONE 2018: 13(11): 1-15.

8) Slomp FM, Bara TS, Picharski GL, et al. Association of cigarette smoking with anxiety, depression, and suicidal ideation among Brazilian adolescents. Neuropsychiatric Disease and Treatment 2019: 15: 2777-808.

9) Hill C. Trends in tobacco smoking and consequences on health in France. Prev Med 1998; 27(4): 51419.

10) McCreadi RG. Diet, smoking and cardio-vascular risk in people with schizophrenia. British Journal of Psychiatry 2003; 183: 534-39.

11) George TP, Vessicchio JC, Termine A, et al. Effects of smoking abstinence on visuospatial working memory function in schizophrenia. Neuro- ${ }^{-}$sychopharmacology 2002; 26(1): 75-85.
12) Glassman $\mathrm{AH}$. Cigarette smoking: implications for psychiatric illness. Am J Psychiatry 1993; 150(4): 546-53.

13) Taneichi $S$, Umekage T, Sasaki $T$, et al. Smoking and depression, in relation to industrial mental health. Industrial Mental Health 2012; 20 (2): 127-34 (in Japanese).

14) Kalman D, Morissette SB, George TP. Comorbidity of smoking in patients with psychiatric and substance use disorders. Am J Addict 2005; 14: 10623.

15) Chaiton MO, Cohen JE, O’Loughlin J, et al. A systematic review of longitudinal studies on the association between depression and smoking in adolescents. BMV Public Health 2009 ;22: 356-70.

16) Suzuki S, Aoki S, Yanai H. The THI handbook/ methods and applications of the Total Health Index. Tokyo: Shinohara Publishier, 1989 (in Japanese).

17) Suzuki S, Roberts RE. Methods and applications in mental health surveys: the Total Health Index. Tokyo: University of Tokyo Press, 1991.

18) Hayashi R, Iwasaki M, Otani, T, et al. Body mass index and mortality in a middle-aged Japanese cohort. J Epidemiol 2005: 15: 70-77.

19) Asano H, Takeuchi K, Koyama $H$, et al. Predictive validity of the Total Health Index for all-cause mortality assessed in the Komo-Ise cohort. J Epidemiol 2008; 18(2): 68-76.

20) Li Yingzi, Suzuki S, Wakimoto Y, et al. Household income and mortality risk related to different sociodemographic characteristics in Japanese men: a prospective cohort study. Jap J Health Human Ecology 2019; 85(5): 108-20.

21) Iijima Hisaka, Suzuki S, Koyama H, et al. Agricultural workers in a cohort of middle-aged Japanese women showed better health status than did women with other occupations. J Rural Med 2018; 131(1): 57-63.

22) Kamada T, Kawano S, Tsuji S. Review: Smoking and the digestive system. J Gastroenterology 1995; 30: 803-08.

23) Garrow D, Delegge MH. Risk factors for gastrointestinal ulcer disease in the U.S. population. Digestive Diseases and Sciences 2010; 55(1): 66-72.

24) Wetter DW, Young TB. The relation between cigarette smoking and sleep disturbance. Preventive Medicine 1994; 23(3): 328-34.

25) Phillips BA, Danner FJ. Cigarette smoking and sleep disturbance. Preventive Medicine. Arch Intern Med 1995; 155(7): 734-37.

26) de Leon J, Diaz FJ. A meta-analysis of worldwide 
studies demonstrates an association between schizophrenia and tobacco smoking behaviors. Schizophrenia Research 2005; 76(2-3): 135-57.

27) Johnson JG, Cohen P, Pine DS. Association between cigarette smoking and anxiety disorders during adolescence and early adult hood. JAMA 2000; 284(18): $2348^{-51 .}$

28) Fluharty M, Taylor AE, Grabski M, et al. The Association of cigarette smoking with depression and anxiety: A systematic review. Nicotine \& Tobacco Research 2017: 3-13.

29) Pratt LA, Brody DJ. Depression and smoking in the
U.S. household population age 20 and over, 20052008. NCHS data brief 2010; 34: 1-8.

30) Pope CA 3rd, Burnett RT, Turner MC, et al. Lung cancer and cardiovascular disease mortality associated with ambient air pollution and cigarette smoke: shape of the exposure-response relationships. Environ. Health Perspectives 2011; 119(11) 1616-21.

31) Thun MJ, Carter BD, Feskanich D, et al. 50-year trends in smoking-related mortality in the United States. N Engl J Med 2013; 368(4): 351-64.

(Receaved 3.23.2020 ; Accepted 9.10.2020) 


\title{
Smoking has physical and psychoactive effects, and heavy smoking is associated with depression
}

\author{
Netti HERAWATI, Shosuke SUZUKI, Hiroshi KOYAMA \\ and Kunihiko HAYASHI
}

Jpn J Health \& Human Ecology, 86 (6) 273-280, 2020

\section{和文抄録}

\begin{abstract}
喫煙の心身への影響が，有病・死亡リスク調査および症状調査票 THI によって日本人中年男性 集団 3,376 名を対象者とした追跡疫学調査によって定量的に検討された。この集団は喫煙量によっ て, 吸わない，1日 1-19 本吸う，20-29 本吸う，30本以上吸う，の 4 階級に分けられた。 THI は 呼吸器, 消化器, 短気, うつ病, 攻撃性など心身が 15 面に尺度化されており, 各尺度は症状等が 「よくある」 3 点, 「時々ある」 2 点などと点数化されて個人毎に尺度得点化される，尺度得点が高 いことは，ある尺度を構成する症状等が多いあるいは強いことを意味する.

喫煙本数が高くなるにつれて呼吸器尺度, 消化器尺度, 夜更かし生活等の尺度得点の喫煙度に よる階級の集団の平均值は線型に大きくなった。他の他愁訴, 短気, 気懸り, うつ病などの 7 尺 度は, 線型でなく大量喫煙者のみ尺度得点が高くなる $\mathrm{J}$ 字型の量反応曲線であった. 神経質尺度と 心身症尺度は 4 つの喫煙クラスで平均尺度得点は変わらずほぼ一定していた．肺がんの死亡リス クは大量喫煙者で特に高かった（死亡リスク比 $=3.71 ）$. 大量喫煙者の割合はうつ病者群のみで高 かった $(\mathrm{p}=0.0014)$.
\end{abstract}

